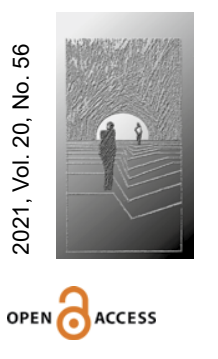

Kamilla Frejusz

http://orcid.org/0000-0001-7620-6599

Akademia Katolicka w Warszawie Collegium Bobolanum kamifrejusz@gmail.com DOI: $10.35765 / \mathrm{hw} .2173$

\title{
Implikacje ignacjańskiego praesupponendum w dialogu wychowawczym
}

\section{STRESZCZENIE}

CEL NAUKOWY: Celem artykułu jest ukazanie implikacji ignacjańskiej zasady praesupponendum we współczesnym dialogu wychowawczym.

PROBLEM I METODY BADAWCZE: Przedstawiony problem badawczy dotyczy odpowiedzi na pytania: Dlaczego warto dziś korzystać w dialogu wychowawczym ze wskazań zawartych w ignacjańskiej idei praesupponendum? Na ile wskazania zawarte w praesupponendum odpowiadają współczesnym problemom, na jakie napotyka dialog wychowawczy? Jakie praktyczne wskazówki zawarte w praesupponendum znajdują dziś swoje odniesienie $w$ dialogu wychowawczym? W artykule zastosowano metodę egzegetyczną oraz analityczno-syntetyczną literatury przedmiotu.

PROCES WYWODU: Na podstawie opracowań naukowych literatury przedmiotu dokonano analizy ignacjańskiej zasady praesupponendum. Przedstawiono czterostopniową gradację jej treści w odniesieniu do sytuacji, które mogą zaistnieć w dialogu wychowawczym.

WYNIKI ANALIZY NAUKOWEJ: Z przeprowadzonych analiz wynika, że treść praesupponendum wpisuje się w problematykę współczesnego dialogu wychowawczego. Poszczególne człony, na które podzielona została ta zasada, odpowiadają konkretnym sytuacjom, z jakimi może mierzyć się dialog wychowawczy.

WNIOSKI, INNOWACJE, REKOMENDACJE: Wytyczne, jakie wynikają się z analizy ignacjańskiej zasady praesupponendum, są w pełni adekwatne do współczesnych sytuacji wychowawczych. Wskazania ignacjańskiej zasady mogą ubogacać i wnosić wiele nowych treści w rozumienie dialogu wychowawczego. Kluczowe są tu przede wszystkim: postawa otwarcia i zrozumienia, umiejętność korygowania z miłością oraz poszukiwania wszelkich możliwych środków w celu pomocy wychowankowi w jego integralnym rozwoju.

\section{$\rightarrow$ SŁOWA KLUCZOWE:}

\author{
DIALOG WYCHOWAWCZY, PRAESUPPONENDUM, \\ WYCHOWANIE, PEDAGOGIA IGNACJAŃSKA, \\ MIŁoŚĆ WYCHOWAWCZA
}




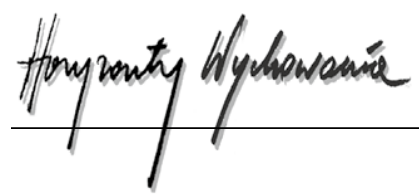

ABSTRACT

The Implications of Ignatian Praesupponendum in Educational Dialogue

RESEARCH OBJECTIVE: The aim of this article is to demonstrate the implications of the Ignatian principle of praesupponendum in the contemporary educational dialogue.

THE RESEARCH PROBLEM AND METHODS: The research problem raises the following questions: Why are the precepts of the Ignatian concept of praesupponendum relevant in the educational dialogue today? To what extent do the precepts of praesupponendum respond to the contemporary problems encountered in educational dialogue? What practical indications of praesupponendum are relevant in the contemporary educational dialogue? This paper employed an exegetic and an analytical-synthetic method with regard to the literature in the field.

THE PROCESS OF ARGUMENTATION: The Ignatian principle of praesupponendum was analyzed on the basis of scientific literature available in this field. A four-step gradation of its content was presented with regard to the situations that can occur in educational dialogue.

RESEARCH RESULTS: The performed analyses demonstrate that the content of praesupponendum corresponds to the problems of the contemporary educational dialogue. The component parts into which the principle was divided are consistent with specific situations that educational dialogue may be confronted with.

CONCLUSIONS, INNOVATIONS, AND RECOMMENDATIONS: The indications that derive from the analysis of the Ignatian principle of praesupponendum are fully relevant to the contemporary educational situations. Its precepts may advance and enrich our understanding of educational dialogue through its pivotal concepts that include: the attitude of openness and understanding, the ability of loving correction and seeking all appropriate means of supporting the mentee in their holistic growth.

\section{$\rightarrow$ KEYWORDS: EDUCATIONAL DIALOGUE, PRAESUPPONENDUM, EDUCATION,} IGNATIAN PEDAGOGY, EDUCATIVE LOVE

\section{Wprowadzenie}

Dialog od zawsze stanowił fundamentalną zasadę wychowania. Nie ma wychowania bez dialogu. W jaki sposób dialog wychowawczy się formował, jakie zasady przyjmował, jakim podlegał uwarunkowaniom i zmiennym, uświadamia nam historia wychowania. Ważne miejsce w tej historii zajmuje wychowanie jezuickie oparte na duchowości ignacjańskiej, a w niej tzw. zasada praesupponendum. Celem artykułu jest ukazanie implikacji tej ignacjańskiej zasady we współczesnym dialogu wychowawczym. Udzielona zostanie odpowiedź na pytanie: Dlaczego warto dziś w dialogu wychowawczym korzystać ze wskazań zawartych w praesupponendum? Jeśli z jednej strony zasada ta 
wydaje się szczególnym wyzwaniem, to z drugiej stanowić może ważną pomoc w niełatwym - zwłaszcza w kontekście dokonujących się zmian - współczesnym procesie wychowania. Jako klucz do zrozumienia idei praesupponendum oraz przełożenia jej na potrzeby dialogu wychowawczego przyjęta zostanie przeanalizowana przez Aleksandra Jacyniaka struktura poczwórnej gradacji tej ignacjańskiej zasady. Każdy z czterech stopni (poziomów) tej struktury nawiązuje do różnych sytuacji, jakie mogą zaistnieć w relacjach międzyludzkich (Jacyniak, 2009), a więc także w procesie wychowania. W niniejszym artykule, jak już zaznaczono, treści te odniesione zostaną do sytuacji dialogu wychowawczego. Dlatego struktura artykułu podporządkowana zostanie przedstawionej czterostopniowej gradacji treści praesupponendum.

Zasadę praesupponendum, nazywaną złotą regułą porozumienia i dialogu (Jacyniak, 2010), odnajdujemy w Ćwiczeniach duchowych św. Ignacego Loyoli. Choć dzieło to nie jest pedagogicznym traktatem, to, jak zauważa Józef Augustyn, w ostatnich dziesięcioleciach ośrodki wychowawcze i edukacyjne prowadzone przez jezuitów na całym świecie odkrywają w Ćwiczeniach duchowych niezwykłą intuicję pedagogiczną św. Ignacego (Augustyn, 2005). Dowodem tego są także różne dokumenty dotyczące pedagogii ignacjańskiej, jak chociażby opublikowany w 2006 r. tekst pt. Charakterystyczne cechy jezuickiego wychowania. Zasada praesupponendum umieszczona została w uprzywilejowanym miejscu książeczki Ćwiczeń duchowych. Znajduje się po Uwagach wstępnych, czyli Adnotacjach, oraz tytule, a przed tzw. „Fundamentem” Ćwiczeń. Odnosi się do relacji międzyludzkich oraz proponuje postawę poszukiwania zrozumienia i życzliwości w dialogu z drugim człowiekiem. Dotyczyć to może różnych środowisk: kościelnych, społecznych, wychowawczych.

Dziś, z perspektywy niemal pięciu stuleci od zaistnienia praesupponendum, dostrzega się jego wielką głębię oraz uniwersalne znaczenie. Może być ono zastosowane bez żadnej korekty czy uwspółcześnienia do całej rzeczywistości ludzkiego dialogu, obecnego w dzisiejszym świecie oraz porozumienia poszukiwanego w różnych zakresach ludzkiego życia (Jacyniak, 2010, s. 12-13).

Co jednak w owej zasadzie praesupponendum może znaleźć zastosowanie we współczesnym dialogu wychowawczym? Czy jej aplikacja może ów dialog ubogacić i uczynić bardziej owocnym?

Zasada praesupponendum sformułowana jest w następujących słowach:

Aby zarówno dający Ćwiczenia duchowne, jak i przyjmujący je bardziej pomagali sobie wzajemnie i postępowali [w dobrem], trzeba z góry założyć, że każdy dobry chrześcijanin winien być bardziej skory do ocalenia wypowiedzi bliźniego niż do jej potępienia. A jeśli nie może jej ocalić, niech spyta go, jak on ją rozumie; a jeśli on rozumie ją źle, niech go poprawi z miłością; a jeśli to nie wystarcza, niech szuka wszelkich środków stosownych do tego, aby on, dobrze ją rozumiejąc, mógł się ocalić (Loyola, 2002, nr 22).

Zauważalna w niej gradacja ukazuje sposób postępowania w czterech różnych sytuacjach mogących zaistnieć w dialogu - także dialogu wychowawczym. 


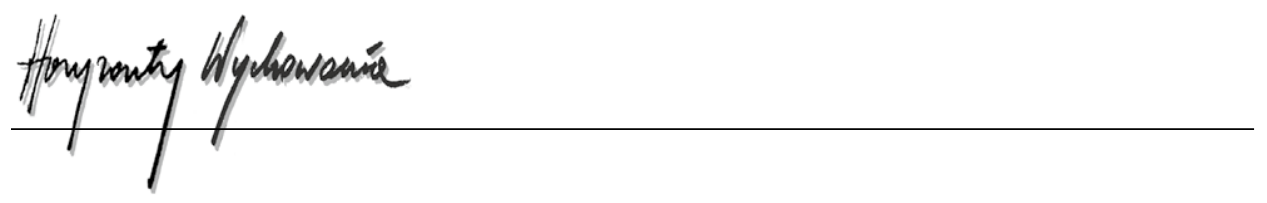

Zanim przeanalizowane zostaną te cztery sytuacje, warto przyjrzeć się kilku aspektom, na które św. Ignacy zwraca uwagę. Przede wszystkim podkreśla on wzajemne oddziaływanie osób będących stronami dialogu. Ignacy Loyola pisze w kontekście ćwiczeń duchowych, czyli rekolekcji. Zauważa, że pomoc i korzyść nie dotyczy tylko przyjmującego ćwiczenia, ale także dającego je. Sytuacja ta ma również miejsce w procesie wychowania, a swoje odzwierciedlenie znajduje w idei współwychowania. W świetle pedagogiki personalno-egzystencjalnej nie tylko uczeń jest wychowywany, ale także wychowawca uczy się od swoich wychowanków (Tarnowski, 2005). Twórca tej pedagogiki, Janusz Tarnowski, pisze, że „wychowawca musi otworzyć się na wartości wychowanka, by dzięki niemu bogacić się duchowo, rozwijać swoje człowieczeństwo przez dialog" (Tarnowski, 1993, s. 72). Zasada ta wypływa także z samej definicji wychowania, ujmowanej chociażby przez Jana Pawła II. Zdaniem papieża „wychowanie jest przede wszystkim obdarzaniem człowieczeństwem - obdarzaniem dwustronnym" (Jan Paweł II, 1994, nr 16). Dlatego też jedną z fundamentalnych zasad, na których bazuje w swojej myśli pedagogicznej Jan Paweł II, jest prawda, że „każdy urzeczywistnia siebie przez bezinteresowny dar z siebie samego. Odnosi się to zarówno do tych, którzy wychowują, jak i do tych, którzy są wychowywani" (Jan Paweł II, 1994, nr 16). Wychowanie stanowi dla papieża proces, „w którym wzajemna komunia osób dochodzi do głosu w sposób szczególny" (Jan Paweł II, 1994, nr 16). Takie ujęcie wychowania jako obustronnego obdarzania człowieczeństwem czy też jako współwychowania pokrywa się ze współczesnym ujęciem zaproponowanym przez Bogusława Śliwerskiego, który wymienia „interi intraakcyjność, czyli obustronne oddziaływanie na siebie podmiotów - wychowawcy na wychowanka i wychowanka na wychowawcę" (Śliwerski, 2015, s. 77). Podobnie jak zasada praesupponendum podkreśla współoddziaływanie na siebie (dającego ćwiczenia i przyjmującego je), tak idea współwychowania (obecna w wielu systemach pedagogicznych) głosi, że wychowanie jest zawsze obustronne. W procesie tym wychowankowie są ,jednocześnie nauczycielami prowadzącymi swego wychowawcę w teren dla niego nieznany" (Tarnowski, 2007b, s. 162).

\section{„Być bardziej skorym do ocalenia niż potępienia”}

Pierwszy z czterech podjętych w artykule stopni praesupponendum brzmi następująco: „każdy dobry chrześcijanin winien być bardziej skory do ocalenia wypowiedzi bliźniego niż do jej potępienia” (Loyola, 2002, nr 22). Kluczowym pojęciem tej frazy jest „ocalenie". Słowo to (salvar) występuje w praesupponendum trzy razy. Choć pojawia się ono w całości Ćwiczeń piętnaście razy, to jednak w każdym innym miejscu odnosi się do zbawienia (dotyczącego poszczególnego człowieka czy też rodzaju ludzkiego). Tylko w tekście praesupponendum termin ten przybiera znaczenie ocalenia czegoś w wymiarze ogólnym, doczesnym, ziemskim. Jak pisze Jacyniak:

Potępienie lub ocalenie kogoś lub czegoś jest najczęściej konsekwencją dokonanej oceny czy wręcz osądu. Ocalanie zawiera w sobie trud wnikania w intencje, motywacje danej 
osoby, poznawania uwarunkowań, w których ona żyje lub które ukształtowały okoliczności wypowiedzenia określonej myśli, opinii, przekonania czy osądu (Jacyniak, 2009, s. 52).

Pragnienie ocalenia wypowiedzi drugiego człowieka zdaje się nieobecne we współczesnym świecie, a tym samym trudno o takie „ocalanie” także w procesie wychowania i nauczania. Nierzadko, jak podkreśla Ewa Dybowska, słychać: „a nie mówiłem”, „a widzisz, miałem rację”, „w końcu wyszło na moje”. Takie podejście zawsze zamyka na dialog i wzajemne zrozumienie, tak nieodzowne w pracy wychowawcy (Dybowska, 2013).

Chęć „ocalenia drugiego” związana jest bezpośrednio z czymś, co w pedagogice dialogu nazywane jest „postawą dialogu”. Predyspozycja, jaką prezentuje wychowawca, musi zakładać nie tylko otwartość na poznanie drugiego, ale także jego dobrą wolę, czyli „chęć ocalenia” drugiego i pomocy mu. Wychowawca musi być „skory” do ocalenia. Zakładamy zatem nie tylko jego dobrą wolę i chęć, ale także gotowość do pomocy. W pedagogice personalno-egzystencjalnej ta gotowość otwierania się na rozumienie, zbliżenie się i współdziałanie (w miarę możności) w stosunku do otoczenia nazywana jest „postawą dialogu” (Tarnowski, 2009). Co więcej, zdaniem Tarnowskiego postawa ta nie odnosi się do poszczególnego partnera dialogu, lecz

(...) jest czymś powszechnym, tzn. obejmuje w zasadzie każdego (...). Mówiąc językiem Bubera, człowiek o postawie dialogu to ktoś posiadający w dużym stopniu możność wytwarzania sfery „pomiędzy” w stosunku do innych (Tarnowski, 1983, s. 343).

To Buberowskie wytwarzanie sfery „pomiędzy” wyraża się w ignacjańskim „byciu bardziej skorym do ocalenia". Dyspozycja wychowawcy w stosunku do wychowanka, zakładająca otwartość na jego „wypowiedź”, stanowi podstawę i fundament dialogu wychowawczego (Frejusz, 2020).

\section{„A jeśli nie może jej ocalić, niech spyta go, jak on ją rozumie”}

Kolejny stopień praesupponendum wskazuje na konkretne formy dialogu, jakimi są dialog rzeczowy i dialog personalny. W dialogu rzeczowym chodzi przede wszystkim o poznanie rzeczywistości. W praesupponendum chodzi o poznanie rozumienia danej rzeczywistości przez drugą osobę. Jest to zgodne także z rozumieniem dialogu rzeczowego w wychowaniu, jaki przedstawia Stanisław Michałowski. Jego zdaniem dialog rzeczowy najczęściej traktowany jest jako

(...) intelektualne poszukiwanie prawdy, w czasie którego „wyostrza” się bystrość i krytycyzm myślenia dążącego do mądrości przez ciągłe stawianie pytań. [Dlatego] stanowi [on] jedną z głównych metod edukacji, sposób bycia paratechnicznego działania pedagoga, odnosi się do wartości treściowej wiedzy oraz celów w postaci uzyskania brakujących informacji (Michałowski, 2017, s. 208). 


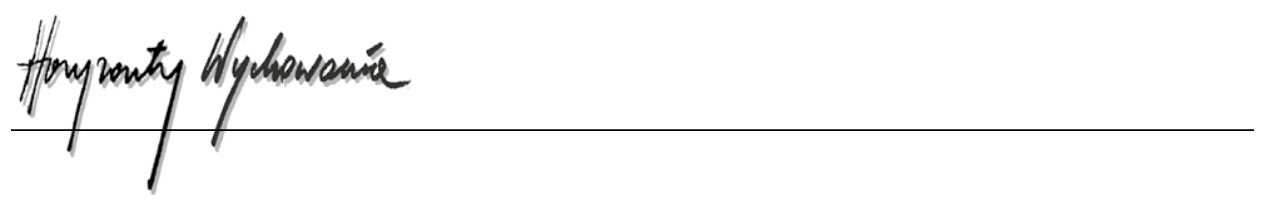

W wychowaniu ten rodzaj dialogu posiada szczególne znaczenie. Przy czym nie chodzi tu tylko o uzyskanie informacji, ale (w myśl praesupponendum) o usiłowanie wyjaśnienia, jak wychowanek rozumie to, co przedstawia, jak rozumie problem, który nazywa. W tym członie omawianej zasady użyte są dwa istotne słowa. Pojęcie inquirir oznaczające „dochodzić”, „,badać”, „wypytywać się”, „dowiadywać się” oraz pojęcie entender oznaczające „rozumieć” i „pojmować” (Jacyniak, 2009). Dialog w tym wymiarze ma przede wszystkim znaczenie poznawcze. Przekładając to na poziom wychowania, wychowawca bez „dopytania” wychowanka o jego rozumienie sytuacji nie jest w stanie

(...) wszechstronnie zaobserwować rzeczywistości i obiektywnie jej ocenić. Zawsze grozi mu jakieś zacieśnienie pola widzenia. Dopiero otwarcie się na to, co widzą i mówią inni, poszerza jego horyzont (Tarnowski, 1983, s. 344).

Zasada zawarta w tym stopniu praesupponendum dotyczy nie tylko dialogu rzeczowego, ale również dialogu personalnego. Trudno bowiem mówić o możliwości otwarcia się wychowanka, wytłumaczenia swojego rozumienia rzeczywistości bez przedstawienia szerszego kontekstu swojego postrzegania. W dialogu personalnym „partnerzy zaczynają mówić nie o czymś, co znajduje się poza nimi, lecz o własnych upodobaniach, uczuciach, doznaniach, radościach i klęskach" (Tarnowski, 1983, s. 344). Dialog taki zakłada otwarcie przed wychowankiem i wychowawcą swojego „wnętrza”, ujawnienia swoich najgłębszych przeświadczeń, uczuć, wprowadzenia w „tajniki naszego ja”. Nie jest on bowiem tylko formą konwersacji, wymiany myśli czy też komunikacji. Jak podkreśla Bogusław Milerski, konieczną przesłanką dialogu ,jest podmiotowa obecność osób. Dialog opiera się bowiem na relacyjnej strukturze bytu ludzkiego (...). W dialogu nie odbieram drugiego jedynie przez pryzmat fizjonomii, estetyki ciała i ubioru czy profesjonalnych kompetencji, lecz z perspektywy jego obecności jako osoby" (Milerski, 2009, s. 37).

W kontekście omawianego członu praesupponendum warto jeszcze raz przyjrzeć się samemu pojęciu „rozumienia”, które w pedagogice dialogu zajmuje szczególne miejsce. Słowo to (powtarzające się w omawianej zasadzie aż trzy razy) w praesupponendum ma równie istotne znaczenie. Chodzi o to, aby wychowanek najpierw wytłumaczył, jak rozumie swoją wypowiedź, a następnie, jeśli rozumie ją źle, aby zrozumiał ją właściwie. Trzykrotne użycie terminu „rozumienia” sygnalizuje, zdaniem Jacyniaka, wielkie przeświadczenie Ignacego o potrzebie poznawania sposobu myślenia i wartościowania drugiego człowieka (Jacyniak, 2009). Zdolność do rozumienia siebie, innych, świata dana jest każdej osobie w różnym stopniu i zakresie. Jednakże, jak słusznie stwierdza Urszula Ostrowska,

(...) środowisko, w którym człowiek żyje, procesy edukacyjne, w których uczestniczy indywiduum, aktywność własna podmiotu, a także spotkania i dialogi, w których on bierze udział, znacząco decydują o tym, czy owa zdolność w ciągu życia poszczególnych osób rozwinie się, udoskonali, czy pozostanie niedostrzeżona, zatracana, a nawet unicestwiona $(2016$, s. 39). 
Zasada praesupponendum wyraźnie podkreśla konieczność doprowadzenia wychowanka do coraz lepszego rozumienia swojej wypowiedzi, a ostatecznie do coraz pełniejszego rozumienia siebie. Jest to ważny aspekt ignacjańskiej zasady i całej pedagogii ignacjańskiej. Kwestia rozumienia, również w procesie wychowania, wydaje się współcześnie pomijana i niedoceniana, a przecież dialog i rozumienie są nierozłączne. Interesującą analogię ich związku przedstawiła w jednym ze swoich artykułów Dorota Jankowska. Jej analizy doprowadziły ją do wniosku, że „rozumienie i dialog mogą być traktowane jako differentia specifica ludzkiej egzystencji” (Jankowska, 2016, s. 64). Porównuje ona rozumienie i dialog do awersu i rewersu monety ludzkiej egzystencji. Jej zdaniem nie jest

(...) szczególnie istotne, który z tych procesów (rozumienie czy dialog) stanowi opisujący "awers”, wyrażający to, co zasadnicze, a który „rewers” - dopowiadający i uzupełniający. Ważniejsze wydaje się, że są nierozerwalnie zespoloną całością (Jankowska, 2016, s. 64).

W perspektywie postawionego pytania o rozumienie swojej wypowiedzi przez wychowanka szczególnie znaczący jest także aspekt zaufania. Trudno mówić w ogóle o możliwości otworzenia się wychowanka na dialog, o jego chęci wytłumaczenia swojego rozumienia rzeczywistości w sytuacji braku zaufania do wychowawcy. O ile bowiem w dialogu rzeczowym mogłoby wystarczyć uznanie większych bądź mniejszych kompetencji partnera, o tyle dialog personalny zakłada wzajemne zaufanie jako podstawowy warunek (Tarnowski, 1983). Zdaniem Bubera zaufanie oznacza dla wychowanka

(...) oswabadzające przeświadczenie o istnieniu ludzkiej prawdy, prawdy ludzkiej egzystencji. Gdy zaufanie ucznia zostało już zdobyte, jego opór przeciwko wychowaniu ustępuje miejsca niezwykłemu zdarzeniu: akceptuje nauczyciela jako osobę. Czuje, że może mu zawierzyć, że wychowawca nie traktuje go jako przedmiotu, lecz bierze udział w jego życiu, że zaafirmował go, zanim zapragnął wywierać na niego wpływ (Buber, 1968, s. 917).

Wydaje się to szczególnie istotne w sytuacji przedstawianej w omawianym tu członie praesupponendum. Zanim bowiem wychowawca wykona kolejny krok, jakim jest upomnienie z miłością, musi najpierw zdobyć zaufanie wychowanka. Tylko wówczas takie upomnienie (choć dokonane z miłością) może zostać przyjęte w postawie otwartości, nawet jeśli w pełni nie zostanie zrozumiane.

\section{„A jeśli on rozumie ją źle, niech go poprawi z miłością"}

Kolejny człon praesupponendum dotyczy umiejętności korygowania z miłością. Ten etap dialogu wydaje się szczególnie trudny w procesie wychowania. Fundamentalną kwestią tej części ignacjańskiej zasady jest miłość. Ignacy, mówiąc o „poprawianiu”, łączy to słowo z miłością. Dokonując egzegezy tego członu praesupponendum poprzez odwołanie się do współczesnych egzegetów, Jacyniak stwierdza, że Ignacy chciał w ten 


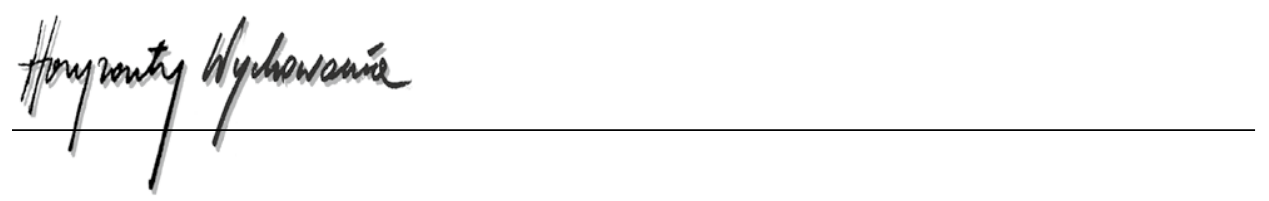

sposób podkreślić, iż to właśnie miłość powinna inspirować do poprawienia bliźniego popełniającego błąd i do poszukiwania odpowiednich argumentów. Natomiast, jeśli

(...) czyjaś wypowiedź, konkluzja czy deklaracja jest niemożliwa do zaakceptowania z punktu widzenia obiektywnego i subiektywnego, należy poprawić ją z miłością dlatego, że zdobywa ona serce i przysposabia umysł do przyjęcia racji pozwalających zrozumieć za i przeciw danej wypowiedzi (Jacyniak, 2009, s. 58).

Na wartości miłości opiera się także jeden z rodzajów dialogu wychowawczego, jakim jest dialog egzystencjalny. „Poprawienie” z miłością czy też stawiane w tak rozumianym dialogu pytanie egzystencjalne dotyka twórczego myślenia będącego próbą spojrzenia na całość, jaką stanowi wizja i cel własnego życia oraz innych. Miłość w dialogu egzystencjalnym oznacza całkowite poszanowanie wychowanka. Jak pisze Stanisław Chrobak, miłość w wychowaniu musi być „mądra, odrzucająca chorobliwą przesadę sprowadzającą człowieka do roli instrumentu. Miłość wychowawcza ma prowadzić wychowanka ku pełnej dojrzałości, odpowiedzialności i samodzielności” (Chrobak, 2016, s. 92). Tak rozumiana miłość daje możliwość „korygowania” wychowanka. Bez miłości działanie to najczęściej nie przyniesie najmniejszych skutków, a wręcz może przyczynić się do wyrządzenia krzywdy wychowankowi. Tylko dzięki miłości wychowawca nie stawia siebie „ponad” wychowankiem, nie występuje w roli pouczającego, wiedzącego lepiej, posiadającego odpowiedzi na wszystkie pytania. „Korygowanie” wychowanka w dialogu egzystencjalnym nie może nigdy dokonywać się z punktu widzenia kogoś, kto jest ponad innym.

Jeżeli bowiem pedagog zapragnie „uczłowieczyć” wychowanka z przekonaniem, jakoby sam już osiągnął właściwe człowieczeństwo, sytuacja staje się niebezpieczna. Wychowanie polega bowiem na odkrywaniu i rozwoju człowieczeństwa po obu stronach procesu pedagogicznego. Oczywiście, odpowiedzialność niewspółmiernie większa i wymagania ciążą na osobie wychowawcy. Świadomość jednak, że nie jest on jeszcze doskonałym człowiekiem, powinna mu stale towarzyszyć. Wtedy właśnie i tylko wówczas, jeśli (...) świadom jest swej niedoskonałości, może pomagać również niedoskonałym uczniom (Tarnowski, 2007a, s. 78).

\section{„A jeśli to nie wystarcza, niech szuka wszelkich środków stosownych do tego, aby on dobrze ją rozumiejąc, mógł się ocalić"}

Nawet wówczas, kiedy wykorzystane zostały już wszystkie środki, jakie daje dialog wychowawczy, praesupponendum nie dopuszcza możliwości „rezygnacji” z podjęcia kolejnych kroków, aby „ocalić” wychowanka. Czym jednak jest owo „szukanie wszelkich środków stosownych" do tego, aby wychowanek, rozumiejąc swoją wypowiedź (siebie), mógł siebie ocalić? Jak zauważa Jacyniak, w tym punkcie praesupponendum Ignacemu chodzi o zachętę „do wytrwałego poszukiwania prawdy i dobra, motywowanego duchem autentycznej chrześcijańskiej miłości” (Jacyniak, 2009, s. 59). Odniesienie do „wszelkich możliwych środków” przywołuje na myśl wspomniany już rodzaj dialogu egzystencjalnego. Dialog ten bowiem 
(...) zachęca do odwagi wytaczania ostatecznych celów działania (...). Dotyka rdzenia osoby, jej najgłębszego „ja” i prowadzi w rezultacie do istotnej, gruntownej przemiany myśli, uczuć i działań człowieka. Prawidłowo przeżywane spotkania dialogowe powodują, że osoba ludzka chce się zmienić, pragnie stawać się coraz lepsza i bliższa ideałowi prawdziwego człowieka (Michałowski, 2017, s. 265).

Dialog egzystencjalny wręcz zakłada szukanie wszelkich możliwych środków dla „ocalenia" wychowanka (Frejusz, 2020).

W kontekście omawianej tu części praesupponendum podkreślić należy, że to nie wychowawca ocala wychowanka, ale to on sam - dzięki właściwemu rozumieniu ocala siebie samego. Ta uwaga ma swoje konsekwencje również we współczesnym wychowaniu i w pewnym sensie powiązana jest ze wspomnianą już ideą współwychowania, niemniej jeszcze bardziej kładzie ona nacisk na samodzielność wychowanka, na przyznanie mu całkowitej niezależności w kierowaniu swoim życiem. Wychowanie, jak słusznie zauważa Dybowska, nie polega przecież na tym, „aby uzyskać prawidłową odpowiedź, którą dorosły (wychowawca, nauczyciel, rodzic) ma zakodowaną w głowie, lecz na szacunku wobec samodzielności młodego człowieka w dochodzeniu do prawdy i trosce o wspólne poszukiwanie tego, co chce mu się ukazać jako prawdę i większe dobro" (Dybowska, 2013, s. 169). To ważne, aby wychowawca miał świadomość, że jest tylko narzędziem, pomocą w procesie dochodzenia do jakiejś prawdy w życiu wychowanka. Taka świadomość niesie za sobą jednocześnie uwolnienie z niepotrzebnej (często przesadnie nakładanej na siebie) odpowiedzialności za każde działanie i ostateczne decyzje wychowanka.

\section{Zakończenie}

Ignacjańskie praesupponendum zawiera wiele wskazań i podpowiedzi dla współczesnego dialogu wychowawczego. Choć zasada ta została spisana prawie 500 lat temu, to jej treść odnajdywała i nadal odnajduje swoje zastosowanie w procesie wychowania. Wytyczne zawarte $w$ tekście praesupponendum, przedstawione $w$ artykule $w$ czterostopniowej gradacji, odnajdujemy w wielu współczesnych nurtach wychowania. Co więcej, wskazania te są wciąż adekwatne do istniejących konkretnych sytuacji wychowawczych. Po pierwsze ignacjańska idea przypomina o wzajemnym oddziaływaniu osób będących stronami dialogu wychowawczego. Pomimo wielu analiz podejmowanych $w$ literaturze przedmiotu dotyczących tego tematu wydaje się, że we współczesnym procesie wychowania wciąż zapomina się o idei współoddziaływania. Zasada współwychowania (choć obecna teoretycznie w wielu nurtach pedagogicznych) często pomijana jest we współczesnym procesie wychowania. Idea wzajemnego obdarzania się swoim człowieczeństwem z pewnością zasługuje na bardziej pogłębione analizy i interpretacje $w$ badaniach pedagogicznych. Po drugie proponowana w praesupponendum postawa wyrażająca się w „chęci ocalenia" wypowiedzi drugiej osoby stanowi kolejne wyzwanie dla dialogu wychowawczego. Warto zadawać pytanie współczesnym wychowawcom o ich motywacje. 


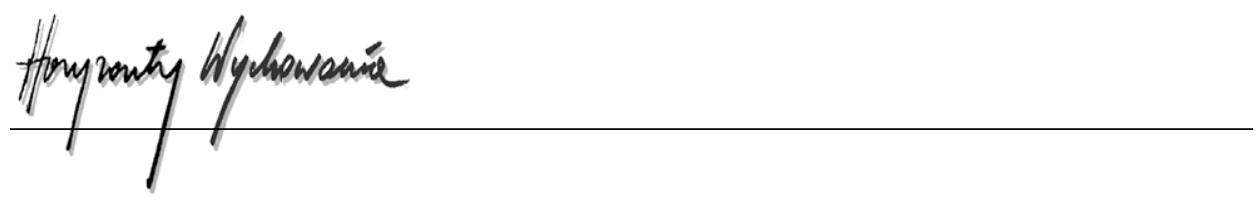

Warto - zwłaszcza w kontekście instrumentalnego traktowania zawodu pedagoga - przypominać o jego powołaniu i szczególnej misji. Bez tej perspektywy trudno wymagać od przyszłych pedagogów otwartości i gotowości w niesieniu pomocy wychowankom. Po trzecie podkreślony w praesupponendum wysiłek i usiłowanie zrozumienia wychowanka stanowi kolejne wyzwanie we współczesnym dialogu wychowawczym. Tak często bowiem mamy do czynienia z postawami, kiedy wychowawcy za wszelką cenę chcą „wytłumaczyć” wychowankom, jak oni powinni daną sytuację rozumieć. Tylko nieliczni pedagodzy próbują uczciwie i szczerze wnikać w to, jak sam wychowanek daną sytuację pojmuje. Ta wskazówka wydaje się kluczem do wielu współczesnych nieporozumień pedagogicznych. Umiejętność „wydobycia” z wychowanka jego sposobu postrzegania i rozumienia konkretnego problemu stanowi pewien rodzaj sztuki wychowawczej. Tylko dzięki niej proces wychowawczy pomaga wychowankowi rozwijać zdolność rozumienia, nie tylko siebie, ale także otaczającego go świata. Po czwarte nie ma prawdziwego dialogu wychowawczego bez miłości. Bez niej, zgodnie z założeniami praesupponendum, niemożliwe jest osiągnięcie jakichkolwiek owoców „korygowania” wychowanka. Co więcej, samo korygowanie nigdy nie powinno dokonywać się bez miłości. Bez niej niemożliwa staje się także akceptacja wychowanka z jego decyzjami i ostatecznymi wyborami. Po piąte ignacjańska zasada nie pozwala nigdy „zrezygnować” z pomocy wychowankowi. Prowadzący dialog wychowawczy zobowiązany jest do szukania wszelkich możliwych środków mających na celu pomoc wychowankowi w zrozumieniu siebie i swojej sytuacji życiowej. Ostatnia wskazówka płynąca z praesupponendum dotyczy uznania, że to sam wychowanek ostatecznie ocala siebie. To zadanie nie należy do wychowawcy. Ta zasada jest szczególnie istotna w kontekście coraz częściej dostrzegalnego problemu wypalenia zawodowego wychowawców, podejmowanego we współczesnych badaniach. Zbyt duże obciążenie, nie tylko wymiarem pracy, ale i odpowiedzialnością, często jest powodem nie tylko rezygnacji z pracy wielu pedagogów, ale i niepodejmowania tego zawodu przez młodych ludzi. Ignacjańska zasada praesupponendum, a przede wszystkim proponowana przez nią postawa otwarcia i zrozumienia, umiejętność korygowania z miłością oraz poszukiwania wszelkich możliwych środków w celu pomocy wychowankowi w jego integralnym rozwoju, nie tylko znajduje swoje zastosowanie we współczesnym dialogu wychowawczym, ale także stanowi dla niego konkretne wyzwania i podpowiedzi.

\section{BIBLIOGRAFIA}

Augustyn, J. (2005). Wstęp. W: W. Królikowski, Duchowy rozwój. Dynamika Ćwiczeń Duchowych św. Ignacego Loyoli (s. 7-12). Wydawnictwo WAM.

Buber, M. (1968). Kształcenie charakteru. Znak, 169-170(7-8), 915-926.

Charakterystyczne cechy jezuickiego wychowania (B. Steczek, tłum.). (2006). W: Podstawy edukacji ignacjańskiej (s. 9-98). Wyższa Szkoła Filozoficzno-Pedagogiczna Ignatianum, Wydawnictwo WAM.

Chrobak, S. (2016). Wychowanie do przebaczenia w pedagogii salezjańskiej. Paedagogia Christiana, 2(38), 85-106. 
Dybowska, E. (2013). Wychowawca w pedagogice ignacjańskiej. Akademia Ignatianum, Wydawnictwo WAM.

Frejusz, K. (2020). Wychowanie jako „dialog i spotkanie” w myśli pedagogicznej Janusza Tarnowskiego. Studium hermeneutyczno-krytyczne. Wydawnictwo Naukowe Collegium Bobolanum.

Jacyniak, A. (2009). Egzegeza ignacjańskiej złotej reguły porozumienia i dialogu (Praesupponendum). Studia Bobolanum, 3, 43-64.

Jacyniak, A. (2010). Zrozumieć bliźniego. Wydawnictwo WAM.

Jan Paweł II. (1994). List do rodzin. Pracownia Duszpasterska Kurii Metropolitalnej.

Jankowska, D. (2016). Kategoria rozumienia i dialogu w myśleniu o człowieku i jego egzystencji - w perspektywie pedagogicznej. W: D. Jankowska i M. Grzelak-Klus (red.), Pedagogika dialogu. Dialog jako droga rozumienia i samorozumienia (s. 54-66). Wydawnictwo Akademii Pedagogiki Specjalnej.

Loyola, I. (2002). Ćwiczenia duchowne (J. Ożóg, tłum.). Wydawnictwo WAM.

Michałowski, S.C. (2017). Pedagogia osoby. Personalistyczne spotkania dialogowe w edukacji. Wydawnictwo Adam Marszałek.

Milerski, B. (2009). Aksjologia kształcenia w perspektywie pedagogiki dialogu. W: E. Dąbrowa, i D. Jankowska (red.), Pedagogika dialogu. Dialog w teorii i praktyce edukacyjnej (s. 30-39). Wydawnictwo Akademii Pedagogiki Specjalnej.

Ostrowska, U. (2016). Fenomen rozumienia świata, siebie i innych w dialogu. W: D. Jankowska, M. Grzelak-Klus (red.), Pedagogika dialogu. Dialog jako droga rozumienia i samorozumienia (s. 34-42). Wydawnictwo Akademii Pedagogiki Specjalnej.

Śliwerski, B. (2015). Współczesne teorie i nurty wychowania. Oficyna Wydawnicza Impuls.

Tarnowski, J. (1983). Próby dialogu z młodymi. Prekatecheza egzystencjalna. Księgarnia św. Jacka.

Tarnowski, J. (1993). Jak wychowywać? Wydawnictwo Akademii Teologii Katolickiej.

Tarnowski, J. (2005). Jak wychowywać? Uczyć się od wychowanków (przyjaciół). Oficyna Wydawnicza Impuls.

Tarnowski, J. (2007a). Paradoks chrześcijańskiej pedagogiki. W: A. Rynio (red.), Wychowanie chrześcijańskie. Między tradycją a współczesnością (s. 70-78). Wydawnictwo KUL.

Tarnowski, J. (2007b). Współwychowanie: przez postawę dialogu ku przyjaźni. W: B. Śliwerski (red.), Pedagogika alternatywna. Postulaty, projekty i kontynuacje. Teoretyczne konteksty alternatyw edukacyjnych i wychowawczych (s. 158-166). Oficyna Wydawnicza Impuls.

Tarnowski, J. (2009). Pedagogika dialogu. W: B. Śliwerski (red.), Teoretyczne podstawy edukacji alternatywnej (s. 141-150). Oficyna Wydawnicza Impuls.

\section{Copyright and License}

This article is published under the terms of the Creative Commons Attribution - NoDerivs (CC BY- ND 4.0) License http://creativecommons.org/licenses/by-nd/4.0/ 